\title{
Arthur Prior and medieval logic
}

\author{
Sara L. Uckelman
}

Received: 13 April 2011 / Accepted: 13 April 2011 / Published online: 17 May 2011

(C) The Author(s) 2011. This article is published with open access at Springerlink.com

\begin{abstract}
Though Arthur Prior is now best known for his founding of modern temporal logic and hybrid logic, much of his early philosophical career was devoted to history of logic and historical logic. This interest laid the foundations for both of his ground-breaking innovations in the 1950s and 1960s. Because of the important rôle played by Prior's research in ancient and medieval logic in his development of temporal and hybrid logic, any student of Prior, temporal logic, or hybrid logic should be familiar with the medieval logicians and their work. In this article we give an overview of Prior's work in ancient and medieval logic.
\end{abstract}

Keywords Diodoros Chronos · Future contingents · Jean Buridan · Medieval logic · Temporal logic $\cdot$ Walter Burley

\section{Introduction}

Currently, Arthur Prior is best known for his work in temporal and hybrid logic, the topics that were his focus and interest in the last two decades of his life. His debt to the ancient Greek philosopher and logician Diodoros Chronos in his development of temporal and tense logic in the 1950 s is widely evinced. ${ }^{1}$ But before his work on temporal logic, he did much research in ancient and medieval logic and worked closely with experts in the fields of medieval logic and philosophy. This research made part of the foundations on which he developed of both temporal logic and hybrid logic.

${ }^{1}$ See, e.g., (Prior 1955, 1957, 1958a; and also Øhrstrøm 1993).

S. L. Uckelman ( $\otimes)$

Institute for Logic, Language, and Computation, Amsterdam, The Netherlands

e-mail: s.l.uckelman@uva.nl 
Prior's debts to and high respect for the Scholastic logicians of the Middle Ages is not often discussed and is also not well-known. ${ }^{2}$ Our goal is to provide information about Prior's work in medieval logic, occasionally touching briefly on relevant topics from ancient logic. We do so in four ways: First, we present an overview of Prior's work in medieval logic, both translations and formal commentaries, which can be found published and in his archives at the Bodleian library. Then, we provide historical information on the logicians who most interested Prior and, third, present some of Prior's hitherto-unpublished notes on translations that he made. Fourth, we expand on the importance of medieval logic to Prior's early research in (Uckelman 2011) elsewhere in this volume, where we argue for a conceptual connection between Prior's interest in medieval logic and his early work in hybrid logic.

The course of our paper is thus: In Sect. 2 we provide a chronology of his work including both published and unpublished research (Sect. 2.1), and we discuss Prior's views on the importance of medieval logic for the modern logician (Sect. 2.2). In Sect. 3 we introduce the reader to five logicians Prior devoted the most time to: Diodoros Chronos (Sect. 3.1), Walter Burley (Sect. 3.2), Jean Buridan (Sect. 3.3), Albert of Saxony (Sect. 3.4), and Peter de Rivo (Sect. 3.5), and we make some concluding remarks in Sect. 4.

\section{Prior's work in ancient and medieval logic}

\subsection{Chronology of research}

Prior's interest in and work on ancient and medieval logic can be traced back to his research for his master's degree in philosophy, completed in 1937, when he worked under the guidance of John Findlay. His thesis was on the history of logic (Grimshaw 2002, p. 483). In 1949, Prior said of Findlay that "I owe to his teaching, directly or indirectly, all that I know of either Logic or Ethics" (Hasle and Øhrstrøm 1997.) In the same year, Benson Mates published a paper on Diodorean implication (Mates 1949) which Prior read and which interested him greatly. This was Prior's first introduction to the logic of Diodoros, which would serve as a foundation and spring-board for much of his later work in temporal logic.

Prior's main involvement with the medieval logicians began when he acquired I.M. Bocheński's Précis de logique mathématique (published in French in 1949, translated into German in 1954, as Grundriß der Logistik, and into English in 1959, as A precis of mathematical logic) and P. Boehner's Medieval Logic. Bocheński's book in particular excited and interested Prior greatly ${ }^{3}$, and while he was teaching at Christchurch, he used it as one of his textbooks (Copeland 1996, p. 3).

The 1950s were the height of Prior's research in medieval logic. During this period he published four papers whose topic was a purely medieval logic subject ((Prior 1952a,b, 1953a,d); while its focus is not strictly medieval, medieval matters are also

\footnotetext{
2 A short acknowledgment of this debt can be seen in Sect. 7 of the first chapter of Prior (1967).

3 Personal communication with Mary Prior. Prior's excitement was so great that she tells the story as if it happened yesterday, rather than nearly 60 years ago.
} 
discussed in Prior (1953b).) and six further papers and reviews on topics in ancient logic (Prior 1953c,e, 1955, 1958b,a, 1959). The issues covered in these papers span a wide range of topics in medieval logic, including consequences, insolubles, supposition theory, ampliation theory, time, tense, and modality.

Additionally, in 1951 Prior completed his ponderous manuscript on The Craft of Formal Logic. ${ }^{4}$ This manuscript is both a textbook in logic and a history of logic. The introductory material contains many references to the works of Peter of Spain, John Duns Scotus, William of Ockham, and Albert the Great. Even at this early date there is clear evidence that the ideas of the medieval authors were pushing him towards the discovery of temporal logic. For example, he says:

The possibility of such extensions of the notion of modality was not unknown to earlier writers. In Peter of Spain, the word 'mode' is used in a broad sense for any sort of qualification of anything, adjectival or adverbial; but more strictly for adverbial qualifications, and most strictly of all for qualifications of the manner of connection between the subject and the predicate, which is what he takes the ordinary modes of necessity, etc., to be. Other 'adverbial' modes express time, or take us right outside propositions altogether, the distinction between indicative and imperative sentences, for example, being classifiable as a 'modal' one. (...That there should be a modal logic of time distinctions has been suggested in our own day by Professor Findlay [note: In Flew's Logic and Language, p. 52 n. $\left.]^{5}, \ldots\right)($ p. 750$)$.

The manuscript was submitted to Clarendon Press at the end of 1951, but it was never published as at over 750 pages, the publishers considered it too long. ${ }^{6}$ Instead, a revised and shortened text was published as Formal Logic in 1955.

While much of the 1960s was devoted to issues relating to his new temporal logic, work on purely historical subjects did not cease. In the early part of the decade, Prior was asked by Oxford University Press to review and comment on a draft of Kneale and Kneale's The Development of Logic. The result was 23 pages of detailed comments which demonstrate encyclopedic knowledge of medieval logical texts then currently available in other than manuscript form. His knowledge is also displayed in the dense and detailed entry he wrote on history of logic for an Encyclopedia of Philosophy. Another interesting text from this period is (Prior 1962a), where Prior draws upon ideas from different medieval authors to explore the formal properties of omniscience, and how they can be represented in a logical fashion.

Throughout the 1960s Prior also maintained regular correspondence with Bocheński, Peter Geach, Ivo Thomas, Desmond Henry, many of whom are nowadays best known for their work in medieval logic. Additionally, he wrote a review of T.K. Scott's translation of Buridan's Sophisms on Meaning and Truth (Prior 1968). ${ }^{7}$ Prior was first

\footnotetext{
4 The manuscript, minus pages 549 and 600, is in Box 22 of the Prior archives.

5 The note is Prior's. The source he refers to is Flew (1951).

6 Personal communication with Mary Prior.

7 The review is not very favorable towards many aspects of Scott's translation. Dissatisfaction with Scott's translation along with an interest stimulated by Prior's work on Buridan was the cause of G.E. Hughes's translation (Hughes 1982). My thanks to the anonymous referee for pointing out this connection.
} 
introduced to this fourteenth-century French logician when Geach sent him some pages from Buridan's Sophismata in $1958 .^{8}$ In the late 1960s, Prior returned many times to new investigations of Buridan's work on sophisms and insolubles (paradoxes). The papers (Prior 1962b), ${ }^{9}$ (Prior 1964), and (Prior 1969) all pertain to material found in Buridan. We discuss Buridan and Prior's work on him further in Sect. 3.3 of this paper and in a separate paper in this volume (Uckelman 2011).

During these two decades, Prior also devoted a lot of energy to producing translations into English of various texts in ancient and medieval logic. The translations are in general undated, but can for the most part be placed in the 1950s. These include both translations and commentaries made for personal use, and collections put together on certain topics for use as course readers. These translations can be found in folders 2 and 3 of Box 9 of Prior's archives in the Bodleian Library, and a complete listing of the contents is available in Appendix A. In Sect. 3 we discuss of a few of the more substantial translations Prior made, along with historical information on the authors of the original texts.

\subsection{Importance of medieval logic}

Prior recognized from a very early point the need for a researcher, of any field, to have a good historical grounding. In an article in the New Zealand Journal of Theology, written in 1933, he says:

I have come increasingly to feel that we moderns need nothing so badly as to pause a while and take a long look back at our beginnings - perhaps beyond them. We need to renew our old concern about primary realities, and tidy up our basic conceptions in theology and metaphysics (Prior 1933, p. 231).

This same sentiment is repeated elsewhere specifically for logicians, reiterating the need for modern logicians to be acquainted with the historical origins of their subject. In a 1961 letter to H.A. Montgomery, he says:

About the difficulties in progressing in formal logic on your own-I had this to cope with too, when I started teaching at Canterbury after the war...I was the only philosopher about the place, and hadn't done anything officially in the field for years...then I got Bochenski's Précis de Logique Mathématique and was fascinated by a Polish notation and corresponded with Bochenski and Lukasiewicz; Lukasiewicz's and Tarski's books (L's Aristotle's Syllogistic...)... - these books, I was going to say, give the subject a formal precision it hadn't in anyone else... Ivo Thomas's translation of Bochenski's Formale Logik... Mates's Stoic Logic and Bochenski's Medieval Logic are good; and if you read Latin,

\footnotetext{
8 A letter from Geach, in Box 2, folder 12 of the Prior archives, dated 02 June of that year says "I enclose a transcription of the treatise on Insolubilia in Buridan's Sophismata; I think you will find them fun. I was much interested in his non-Tarskian theory of truth (with the idea that what is true or false is a sentence token...)."

9 Reprinted in Geach and Kenny (1976).
} 
Walter Burley's De Puritate Artis Logicae Tractatus Longior is good all through. ${ }^{10}$

This shows the importance that Prior put on a modern logician being familiar with his medieval predecessors; he considers their logic on a par with then-available work in modern logic. His respect for Burley is seen also in his review of Boehner's edition of Burley's De Puritate, where he says that

This should surely be a set text in any institution where it can be assumed that students of logic are able to read Latin. The Latin is so easy; the man's problems and interests are modern enough to hold the twentieth-century reader's attention, and his methods medieval enough to teach us something unfamiliar; and I do not know any other medieval logic-book in which you have to wade through as little dross to find as much pure gold (Prior 1958c, p. 127).

Finally, in an unpublished review of Ivo Thomas's translation of Bocheński's History of Formal Logic Prior says:

While Bocheński misses much of this [the medieval advances], he has enough from the medieval writers to make it worth advising mathematicians to look at them-especially at their theories of reference ('supposition') and their treatment of antinomies - and not just at the more obviously relevant modern section (p. 2). ${ }^{11}$

This clearly demonstrates Prior's view that there is much of use and of interest to the modern logician in the works of the medieval logician.

\section{Historical background}

\subsection{Diodoros Chronos}

Diodoros Chronos (Lat. Diodorus Chronus) was born in Iasos, an Ionian town in Caria, sometime towards the end of the fourth century BC. As a young man he studied dialectic with Apollonius, a pupil of Eubulides. After moving to Athens, he set up a school where he taught dialectic. Other philosophers active in Athens at this time include Zeno, Arcesilaus, and Epicurus, the founders of the three Hellenistic schools. Diodoros died in Alexandria during the reign of Ptolemy Soter, sometime after 285. ${ }^{12}$

For Prior's purposes, the most interesting view of Diodoros was his definition of possibility in terms of time: A proposition is possible if it is or will be the case. Correspondingly, a proposition is necessary if it is now and always will be the case, and a proposition is impossible if it neither is now nor will ever be the case.

\footnotetext{
10 Letter to H.A. Montgomery dated 23 May 1961, Box 2, folder 20 of the Prior Archives, Bodleian Library, Oxford. The books referenced are (Bocheński 1949; Lukasiewicz 1951; Bocheński 1961; Mates 1953; Boehner 1952) (Prior misattributes the book to Bocheński), and Burleigh (1951), respectively.

11 The review can be found in Box 5 of the Prior Archives.

12 For more details on Diodoros's life, his philosophy, and his influence on later philosophers, see Sedley (1977).
} 
Mates points out that in these definitions,

Diodorus did not talk the same language, philosophically speaking, that we do; he uses "truth" as though it were a temporal predicate, and he speaks of "becoming true" and "becoming false" or says that a proposition "will be true" or "will be false" (Mates 1949, p. 237).

To twentieth-century logicians working in classical logic, Diodoros's language does not make sense because a proposition is an abstract entity whose properties are fixed and further have always been and will always be fixed. To say that a proposition "will be true" even though it is not now true is nonsensical at best and contradictory at worst. An example of the philosophical language spoken by Mates and his contemporaries is expressed nicely in the Stanford Encyclopedia article on propositions:

Propositions... are the sharable objects of the attitudes and the primary bearers of truth and falsity. This stipulation rules out certain candidates for propositions, including thought- and utterance-tokens, which presumably are not sharable, and concrete events or facts, which presumably cannot be false (McGrath 2006).

Diodoros's view of propositions was that they are concrete tokens whose properties can change over time, such that it is possible to say of a proposition at one time that it is true and at another time that it is false (this view, as we'll discuss further in Sect. 3.3 and (Uckelman 2011), was the norm for ancient and medieval logic). In modern parlance, we could say that the point of departure for Diodoros's views was to attach truth values to specific sentence tokens rather than to the abstract propositions represented by those tokens. It was this move, the recognition that the truth value of one and the same proposition could change over time, that proved crucial for Prior's development of the temporal calculus.

Prior's break with tradition (or, to be more precise, his return to tradition!) did not always gain him immediate converts. In correspondence from the early 1950s, J.J.C. Smart often railed against Prior's move, saying such things as "I think a lot of your (philosophical) puzzles will disappear if you recollect that sentences are neither $\mathrm{T}$ nor F...statements don't change their truth value" (14 August 1952) and "I think it is nonsense to talk of the truth value of a statement changing with time. What happens is that the very same sentence can at one time be used to make a true statement at another a false one" (16 December 1954). ${ }^{13}$ However, through the rose-tinted glasses of hindsight, one cannot deny the utility of Prior's actions in this matter, as the result was many fruitful and interesting developments.

\subsection{Walter Burley}

Walter Burley (Burleigh) was an English logician in the late 13th and early 14th centuries. Burley was born c. 1275 either in or near the village of Burley, Yorkshire (hence his name). He studied first at Oxford, where he was Master of Arts from 1300 to 1310 in Merton College. In 1309 he became the rector of Welbury, Yorkshire, and

13 These letters, and others, can be found in folder 23 of Box 3 of the Prior Archives. 
afterwards travelled to Paris to study and to take holy orders. In 1324 he became a Master of Theology at Paris, and he died around 1344 or shortly thereafter.

Most of Burley's works that are extent are commentaries and expositions on Aristotelian treatises, both logical and non-logical. However, he did write a few original tracts, including the longer treatise De Puritate Artis Logicae Tractatus Longior, written between 1325 and $1328 .{ }^{14}$ De Puritate covers the standard range of topics for a fourteenth-century medieval logical texts. It is divided into two parts; the first part is a discussion of rules of consequences and the second is a tract on syncategorematic terms. A syncategorematic term is one which does not have any meaning on its own but only in the context of a sentence. These are the terms which in modern logical contexts make up the set of logical operators. The syncategorematic terms which Burley discusses are: 'single' (solum) and 'only' (tantum), 'besides' (praeter) and 'except' (praeterquam), 'unless' (nisi), 'begin' (incipit) and 'cease' (desinit), 'not' (non), modal terms, 'and' (et), 'or' (vel), 'whether' (an), 'if' (si), 'in as much' (inquantum, secundum quod), 'all' (omnis), 'both' (uterque) and 'neither' (neuter), 'whole' (totus), 'whatsoever' (quidquid) and 'whosoever' (quicumque), signs of distributive accidents, and 'infinite' (infinitum). (Burley notes that 'infinite' has both a categorematic and a syncategorematic sense; in the categorematic sense, it means 'infinite thing'). Of interest here is the fact that not only are all the standard modern logical connectives included in this list, but also many terms which can be given a logical analysis but which are not in general treated as logical terms in modern classical logic.

As we saw in Sect. 2.2, Prior considered De Puritate, edited and published in 1951, to be one of the best texts by a medieval logician easily available in the 1950s. His published works on Burley include a review of Boehner's edition of De Puritate (Prior 1958c) and a reconstruction of Burley's theory of consequentiae (Prior 1953d). The medieval term consequentia applies to two different types of things. On the one hand, the term consequentia can refer to a hypothetical statement beginning with si 'if'. On the other hand, the term can also be used to refer not to the hypothetical proposition itself but rather to the relation which holds between the antecedent and the consequent. This latter use can be generalized to refer to the relationship between the premises and conclusion of an argument. Hence, the term consequentia covers both what modern logicians would call conditionals and what they would call inference or implication. ${ }^{15}$

In Box 9, folder 2, of the Prior archives in the Bodleian are ten type-written copies of a text by Prior on "Burley on the subdivisions of Suppositio Personalis, and connected topics". This text, a conversational reflection on supposition, has never been published before, and is presented in full in Appendix B.

The medieval theory of supposition is the theory of what objects a term can 'supposit' or stand for; this is to be distinguished from what a term signifies. For example, the term 'man' signifies all men, but, depending on the context in which it is used, may or may not supposit for all men. The signification of a term (which many modern logicians correlate simply with 'meaning') does not vary, but the supposition of term

\footnotetext{
14 See Conti (2004) for a fuller discussion of Burley's life and works.

15 For more information on consequentiae in general, see Boh (1982). For another modern discussion of Burley's theory of consequentiae, see Dutilh Novaes (2006).
} 
(which correspondingly is often interpreted as 'reference' by modern logicians ${ }^{16}$ ) is guided by syntactic features of the sentence in which the term occurs. For example, in the sentence 'All men run', 'men' supposits for all men; that is, its supposition and its signification is the same. However, in 'some man runs', 'man' supposits only for some (unspecified) man, not all men.

The types of supposition that a term can have can be divided into a fairly complex tree of types. In the text below, Prior discusses Burley's division of suppositio personalis, or 'personal supposition'. A term has personal supposition when it supposits for everything of which it can be truly predicated. In our example above of 'All men run', 'men' has personal supposition. For a general introduction to supposition, see Spade (1982).

\subsection{Jean Buridan}

Jean Buridan (Johannes Buridanus, John Buridan) was born at Bethune in Arras, France, shortly before 1300 . He studied and taught at the College of Navarre, then returned to Paris where he taught in the Faculty of Arts and served as rector of the university in 1328 and 1340, before dying in $1358 .{ }^{17}$

As we noted in Sect. 2.1, Prior was introduced to the works of Jean Buridan by Peter Geach in 1958. In the 1960s he produced two substantive translations of Buridan's works, for his own use. The first consists of Chaps. 6 and 8 of Buridan's Sophismata, which discusses various types of sophisms and paradoxes, and is entitled "Entailment, Possibility, and Possible Truth". ${ }^{18}$ The second is a section of Buridan's Questions of Truth, from the text in (Buridani 1518). We discuss the latter here, and leave the former to (Uckelman 2011).

Buridan's Questions of Truth is a discussion of what is meant when it said that at a proposition is true. Prior's translation is 13 type-written pages. By way of introduction, Prior says:

The problems have a certain correspondence with those treated by Tarski in his study "The Semantic Conception of Truth". Thus question 8 is concerned with what Tarski calls the "material criterion of truth", such as is expressed by the equivalence: The sentence 'snow is white' is true if and only if snow is white. Question 11 develops the difficulties involved in this criterion, when applied to sentences which assert their own falsity, just as Tarski's article does. The final part of Tarski's article, in which a definition of what is meant by 'true', fulfilling the requirements of the "material criterion", is developed, corresponds roughly to Buridan's question 7; the interesting problem here, is whether the fourteenthcentury definition of truth in terms of fulfillment of syntactically determined conditions of "supposition" of subject-term with respect to predicate-term, is

\footnotetext{
${ }^{16}$ For both these claims, see, e.g., Moody (1953), also Spade (1982): "The theory of supposition proper is a theory of reference" (p. 192); but see Dutilh Novaes (2006) for a contrary view.

17 See Zupko (2003) and the introduction of Buridan (1966) for more details of his life.

18 Numerous copies of this text can be found in Boxes 6 and 9 of the Prior archives; an additional copy can be found in Box 1 included with the Anderson-Prior correspondence.
} 
equivalent or analogous to Tarski's "formal definition" of truth as satisfaction of a sentential function of zero degree (or containing no free variables) by all objects. The fourteenth-century theory of "suppositio personalis", as developed for example in Albert of Saxony's Summa logicae II, Chap. 1-4, underlies this whole treatment of the meaning of 'true' as applied to categorical statements.

These comments connecting Buridan and Tarski are expanded in Chap. 7 of Prior (1971).

The questions on truth which Prior translated are the following:

7 Whether, for the truth of an affirmative proposition, there is required a composition in the thing or things signified, and for the truth of a negative proposition, a separation or division?

8 Whether every proposition is true, if it is true, by the fact that, as it signifies the case to be, thus the case is, in the thing or things signified?

11 Whether the same proposition can at the same time be true and false, without equivocation?

The final question concerns the double-liar examples, where Plato says that what Socrates says is false, and Socrates says that what Plato says is true (and both say nothing else). In a separate work, Prior translates Book IV, question 6, of Buridan's Sophismata (ed. in Buridani (1518)), which is "whether this word 'being' signifies substance and accidents according to one reason or concept".

These questions all related to the nature of truth, how it attaches to propositions, and paradoxes that arise from both these things. These are the same matters which can be found in the excerpts from Buridan's Sophismata that Prior chose to translate. We discuss two of these sophisms and Prior's semi-formal reconstruction in (Uckelman 2011).

\subsection{Albert of Saxony}

At some point, probably in the late 1950 s, Prior received from G. Donnelly ${ }^{19}$ portions of Albert of Saxony's Summa Logicae. Prior's translation of these excerpts can be found in his archives. The translation is typewritten and is entitled "Selections from the Summa Logicae of Albertus de Saxonia", and contains excerpts from three of the six parts of the treatise. The excerpt from part one is 11 pages; that from part two is 8 pages, including notes for further reading; that from part three is also 11 pages.

Prior gives the following prefatory note:

Albert of Saxony was a leading teacher of the Faculty of Arts at the University of Paris, from about 1350-1380. He was a pupil of Jean Buridan, and was very much influenced by Buridan's teaching in physics and in logic. Albert's work in logic also shows strong influence of William of Ockham, whose commentaries on the logica vetus (on Porphyry, and Aristotle's Categoriae and De Interpretatione) were made the subject of a series of Quaestiones of Albert.

\footnotetext{
19 I have been unable to find out any more information about who G. Donnelly is.
} 


\begin{abstract}
Albert's Summa logicae, while not as rich in philosophical interest as the work of that name by Ockham, is a systematic statement of the logical system of the fourteenth-century scholastics, having a concision and clarity which make it especially useful as a text for modern study of this logical tradition. The portions selected for translation, from the edition of Venice 1522, present the chief definitions, distinctions, and rules which exhibit the structure of the logic as a formal treatment of truth conditions and of the relation of logical consequence. The Treatise is in Six Parts, each part being divided into chapters.
\end{abstract}

From Part One, Prior's translations covers the following topics:

- concerning the term 'sign'

- concerning the term 'term'

- on the second division of terms

- the third division of terms

- on the noun

- on the verb

- concerning terms of first or second intention, and imposition

From Part Two:

- on the supposition of terms

- concerning simple supposition

- on material supposition

- on personal supposition

- on confused and distributive supposition

- rules of supposition of terms

- on ampliation

- on the appellations of terms

From Part Three:

- on the proposition

- on modal propositions-Albert calls 'modal' only those sentences which change the type of inherence indicated by the copula.

- on hypothetical propositions

- on the properties of propositions

Of these topics, we have met with supposition already above. We briefly discuss the four subjects common in medieval logic but no longer a part of modern logic: terms of the first and second intentions, imposition, ampliation, and appellation.

The term 'intention' as used by medieval logicians and philosophers is distinct from the use of the term 'intention' used to mean 'purpose'. The meaning of the term used by the medieval logicians harkens back to an earlier and wider sense of the English word, namely to devote the mind's attention to something (whether this be a course of action or not). The result of such a mental action is an intention. A modern philosopher might define a medieval intention as a concept which is immediately before the mind.

The referent of an intention may be one of two kinds. It may be something extramental, or it may be another intention. Extra-mental intentions are called first intentions, and intentions of the latter kind are called second intentions. It is then clear what 
a term of the first intention or a term of the second intention is: It is a term whose referent is a first intention or a second intention, respectively. For example, the word 'cat' is a term of the first intention, while the word 'genus' is a term of the second intention, since it picks out other concepts, and not real things in the world (even on a very robustly realist view).

The medieval grammarians made a similar distinction, dating back to Porphyry and Boëthius, between words which signify extralinguistic entities (e.g., 'cat') and words which are signs of linguistic entities (e.g., 'noun'). The similarity in the distinctions between first and second intention and first and second imposition resulted in the two often being conflated, confused, and discussed together.

A term's imposition or intention governs the signification of that term. Ampliation and appellation, on the other hand, are connected with reference of a term. The appellation of a term is that which the term can be properly applied to when it is used in a simple present-tensed statement. In the sentence 'Cats are mammals', the appellation of 'cats' is simply all currently existing cats. In early developments of theories concerning the properties of terms (such as William of Sherwood's in the first half of the thirteenth century), appellation played the rôle that supposition would play in later developments. Just as the supposition of a term can change depending on the syntactic rôle of the term in a specific sentence, so too the appellation of a term can be restricted or expanded. When certain syntactic features of a sentence cause the appellation of a term to be expanded, the term is said to have been ampliated. For example, in the sentence 'A man will be running', the term 'man' has been ampliated so that it no longer refers just to currently existing men but also to all possibly future existing men. Modal terms such as 'necessarily' and 'possibly' and tenses such as 'will' and 'were' all have ampliative effect. It is hence understandable why Prior selected for translation the passages he did.

\subsection{Peter de Rivo}

As one might expect, given the large number of his papers which discuss or otherwise refer to the Master Argument of Diodoros Chronos, medieval treatments of future contingents interested Prior greatly. Many of the translations in Box 6 of the archives are of texts dealing with this topic. The most extensive set of translations dealing with future contingents is that of selected passages of texts by Peter de Rivo. The texts were originally published in Baudry (1950). ${ }^{20}$ Prior's translations were completed by the end of January 1958, in Christchurch. There are two copies of the translations in Box 9 of the archives, in folders 2 and 3.

Peter de Rivo, born around 1420 and died in 1499, was an arts student at the University of Louvain. In the decade of 1465 to 1475 , he was involved in a disputation with a member of the theology faculty, Henry van Zomeren, also born around 1420 and died in 1472, on the nature and truth value of future contingent statements, and how to reconcile secular philosophical explanations, such as Aristotle's, with the requirements

${ }^{20}$ An English translation, by Rita Guerlac, of the entire work was not published until 1989, in Baudry (1989). 
of theological doctrine. This dispute was conducted in a series of quodlibet questions. Quodlibetal disputations were held at universities twice a year, generally at Lent and at Advent, where a master of the university would put forward a question and attempt to answer it, and any other questions or objections raised by the audience, and then provide a summary of the arguments for and against the original question.

In a nutshell, the problem was thus: Aristotle's position on future contingents is often held to be that they have no truth value. But this is in contradiction with the theological position of God's omniscience. If God is omniscient, he knows everything, including statements about the future. If God knows a statement about the future, then that statement not only is already true now, but it has always been true. Peter argued, on the side of the arts faculty, that Aristotle's position can be interpreted in a way which is not inconsistent with the theological position. Such an argument had some sympathizers in the theology faculty, who saw the potential for Diodorean-style problem in the standard theological view. But Henry argued on behalf of the traditional theological position (and did so so well that the Bishop of Tournai and the Holy See became involved in the disputation, and twice Peter was forced to retract his views).

The translated selections are (page numbers refer to Baudry (1950)):

- The quodlibet question argued by Peter de Rivo at Louvain in 1965 (70-78).

- Two treatises by de Rivo (80-81, 85-86).

- A fragmental text (89-90).

- A selection from A treatise of Peter de Rivo in answer to a certain work of Master Henry of Zomeren (335-339).

- A selection from Peter de Rivo's solution of certain difficulties about future contingencies (456).

The material present in these texts forms part of the historical discussion of Chap. VII of Prior (1967), where Prior discusses determinism and free will in the context of time and modality.

\section{Concluding remarks}

The preceding survey shows that Arthur Prior's debt to the medieval logicians cannot be disputed. This debt ranges from concepts which he transposed into wholly modern application to course material for classes on a broad spectrum of topics to the intriguing logical puzzles of purely medieval making. Prior took to heart his belief that a researcher should know the history of his field; we have shown that not only should students of Prior be familiar with the historical logicians which inspired him so much, but indeed all students of logic should be, for there is much gold still to be found and very little dross.

Acknowledgments The author wishes to thank Peter Øhrstrøm for the invitation to write this paper, and for putting her in contact with Mary Prior, Arthur Prior's widow, in Oxford. Many thanks are also due to Mary for her permission to study the Prior archives at the Bodleian and for her kind hospitality while in Oxford. The help of Colin Harris in the Modern Papers Room of the Bodleian is also gratefully acknowledged. Research for this paper was partially funded by the project "Dialogical Foundations of Semantics" (DiFoS) in the ESF EuroCoRes programme LogICCC (LogICCC-FP004; DN 231-80-002; CN 2008/08314/GW). 
Open Access This article is distributed under the terms of the Creative Commons Attribution Noncommercial License which permits any noncommercial use, distribution, and reproduction in any medium, provided the original author(s) and source are credited.

\section{Appendix A: Medieval logic manuscripts in the Prior archive}

The bulk of Prior's work on medieval logic can be found in folders 2 and 3 of Box 9 of his archives in the Bodleian. Most of this material dates from 1945 to 1955.

The second folder contains class handouts on medieval logic and philosophy. These include:

- Peter Abelard (c. 1079-1142) on parts and wholes, from Abelard (1956). (trans. Prior, 9 p.).

- St. Thomas Aquinas (c. 1225-1274), On the power of God, Q.III "Of creation", Article 1: Can God create a thing from nothing? (trans. L. Shapcote, 5 p., 7 copies).

- St. Thomas Aquinas, Disputed questions on truth: 14. "On faith. What is it to believe?" (trans. TCP, 2 p.). ${ }^{21}$

- Walter Burleigh (c. 1275-1345) on the subdivisions of suppositio personalis and related topics. (trans. Prior, 3 p., 10 copies). This text is published in Appendix B of this paper.

- Jean Buridan (c. 1295-1358), "Entailment, possibility and possible truth", Sophismata Chap. 8, (trans. Prior, 5 p., 6 copies). Discussed in Sect. 3.3.

- Paul of Venice (c. 1369-1429), "The suppositio of relative pronouns" from the Logica magna. (trans. Prior, 32 p.).

- Peter de Rivo (1420-1499). Passages from texts included in Baudry (1950). (trans. Prior, 21 p.). A second copy is found in the third folder. Discussed in more detail in Sect. 3.5.

- Author unknown, "Is knowledge predicated equivocally of God and of us?" (3 p.). ${ }^{22}$

- Medieval Philosophy: Assorted texts on the existence of God and the ontological argument by Boëthius (c. 480-524), St. Anselm of Canterbury (1033-1109), Thomas Aquinas, and John Duns Scotus (c. 1266-1308). (trans. Prior, 12 p.).

- Medieval Philosophy: Assorted texts on the theory of consequence by Peter of Spain (d. 1277), Robert Kilwardby (c. 1215-1279), William of Ockham (c. 12851349), Jean Buridan, Albert of Saxony (c. 1316-1390), Walter Burleigh, and Paul of Venice. (trans. Prior, 59 p.).

The third folder contains various translations of ancient and medieval texts of Aristotle, Albert of Saxony, Thomas Aquinas, Jean Buridan, Peter de Rivo, Peter of Spain, William of Sherwood (c. 1200-1270), and John Duns Scotus.

- Analogy and the Transcendentals. 1. "Aristotle: Denial of Analogy in Early Writings", 2. "Aristotle: Transitional Period: Exploitation of Analogy, but Natural

\footnotetext{
21 It is not known who TCP is.

22 Per Hasle notes in Hasle and Øhrstrøm (1997) that "The text seems to sum up some Medieval argumentation on the issue. The style is neither Prior's nor that of a Medieval logician."
} 
Priority of Substance not dependent on Focal Meaning Theory", 3. "The Academy: Evidence that the Academy had grasped the notion of Focal Meaning", 4. "Aristotle: Theory of Focal Meaning". (trans. and commentary by Prior, 41 p.).

- Jean Buridan, Questions on Truth. (From Buridani (1518).) (trans. Prior, 36 p.).

- Albert of Saxony, selections from the Summa Logicae (trans. Prior).

- John Duns Scotus, Opus oxoniense, lib.II, dist.III, q.I. (trans. Prior, 10 p.).

- Thomas Aquinas, In Aristotelis Libros Peri Hermeneias et Posteriorum Analyticorum Expositio Liber I, Lectio XIII, 10,11. (trans. Prior, 2 p., 2 copies).

- Medieval Philosophy: Assorted texts on the theory of supposition from William of Sherwood's Introductiones ad logicam, Peter of Spain's Summulae logicales, Thomas Aquinas, Jean Buridan's Sophismata, Albert of Saxony's Perutilis logica, Walter Burleigh's De puritate artis logicae, Paul of Venice's Logica magna, Vincent Ferrer's De suppositionibus dialecticis, Peter Tartaret's Commentary on Peter of Spain's Summulae logicales, and William of Ockham' Summa logicae. (trans. Prior, 32 p.).

- Assorted texts from Peter of Spain's Summulae logicales, Robert Kilwardby's Commentary on Aristotle's Prior Analytics, Pseudo-Scotus's Commentary on Aristotle's Prior Analytics, William of Ockham's Summa logicae, Jean Buridan, Albert of Saxony's Perutilis logica, Walter Burleigh's De puritate artis logicae, Paul of Venice's Logica magna. (Per Halse notes in Hasle and Øhrstrøm (1997) that most of these texts were translated by Ivo Thomas, 27 p.).

\section{Appendix B: "Burley on the subdivisions of Suppositio Personalis, and connected topics", trans. by Arthur Prior.}

In the schemata below, $f(T)$ is some proposition containing the common noun $T$, and $f\left(t_{1}\right)$ is the same proposition with $T$ replaced by a designation of some individual to which $T$ applies, e.g., if $f(T)$ is "Every grammarian is a man", $f\left(t_{1}\right)$ might be "Every grammarian is Socrates". Words like "a" and "some" immediately preceding the term $T$ are dropped when passing from $f(T)$ to $f\left(t_{1}\right)$.

(1) Suppositio determinata: $T$ has determinate supposition in $f(T)$ if and only if

$$
f\left(t_{1}\right) \rightarrow f(T)
$$

and

$$
f(T) \rightarrow f\left(t_{1}\right) \text { OR } f\left(t_{2}\right) \text { OR } f\left(t_{3}\right) \text { OR (etc.) }
$$

For example,

- This man is an animal $\rightarrow$ Some man is an animal.

- Some man is an animal $\rightarrow \underline{\text { This man }}$ is an animal or that man is an animal or (etc.)

(2) Suppositio confusa tantum: $T$ has merely confused supposition if and only if

$$
f\left(t_{1}\right) \rightarrow f(T)
$$


and

$$
f(T) \nrightarrow f\left(t_{1}\right) \text { or } f\left(t_{2}\right) \text { or } f\left(t_{3}\right) \text { etc. }
$$

e.g.,

- Every man is this animal $\rightarrow$ Every man is an animal.

- Every man is an animal $\nrightarrow$ Every man is this animal or every man is that animal or etc.

and again

- Always this man existed $\rightarrow$ Always some man existed.

- Always some man existed $\nrightarrow$ Either always this man existed or always that man existed or etc.

To pass from "Always some man existed" to "Some man always existed" is to pass illegitimately from "man" in merely confused to "man" in determinate supposition. (W.E. Johnson suggests using "A certain man" for the determinate "some man", and "some man or other" for the merely confused.)

Ockham points out that although

- Every man is an animal $\nrightarrow$ Every man is this animal or every man is that animal or etc.

nevertheless

- Every man is an animal $\rightarrow$ Every man (is this animal or is that animal or etc.)

The same may be said with regard to "Every man owns some animal" or "sells some animal", etc.

Note also that while, in singulars

- $X$ is $R$ to $A$ or $B$ or $C$ etc., usually $\rightarrow X$ is $R$ to $A$ or $X$ is $R$ to $B$, etc.,

this is not always so. For while " $X$ kicks $A$ or $B$ or $C$ " $\rightarrow$ " $X$ kicks $A$ or $X$ kicks $B$ or $X$ kicks $C$ ", " $X$ has promised to give me $(A$ or $B$ or $C)$ " $\nrightarrow ~ " X$ has promised me $A$ or $X$ has promised me $B$ or $X$ has promised me $C$ ". ${ }^{23}$ In "I have promised you a horse", "horse" stands for (supponit pro) individual horses "determinately but disjunctively" (Burley).

(3) Suppositio confusa et distributiva. $T$ has confused and distributive supposition if and only if

$$
f(T)=f\left(t_{1}\right)
$$

and

$$
f\left(t_{2}\right) \text { and } f\left(t_{3}\right) \text {, etc. }
$$

e.g.,

Every $\underline{\operatorname{man}}$ is an animal $=\underline{\text { This man }}$ is an animal and that man is an animal, etc.

23 The $\nrightarrow$ was $\rightarrow$ in the original manuscript. This is obviously an error. 
(4) Suppositio confusa et distributiva singulata. Reflexive pronouns referring back to terms with confused and distributive supposition also have this supposition, but "singulated". In such a case we have both

$$
f\left(t_{1}\right) \nrightarrow f(T)
$$

which distinguishes this from (2); and

$$
f(T) \nrightarrow f\left(t_{1}\right)
$$

which distinguishes it from (4).

For example

- Every man sees this man $\nrightarrow$ Every man sees himself

- Every man sees himself $\nrightarrow$ Every man sees this man.

But the supposition is distributive in the sense that

- Every man sees himself $\rightarrow \underline{\text { This man sees this man. }}$

Where the grammatical subject is compounded of a term in the nominative case and one in an oblique case, it will be the logical subject, and distributed in the normal way, if the term in the nominative comes first, as in "Every donkey-of-a-man is running". But where the term in the oblique case comes first, as in "Of every man, some donkey is running", it is this term, and not the whole complex, that is distributed (it amounts to "Every man has a running donkey"). Hence, the following is sophistical:

In every pair of contradictories, one member is true. "You are a donkey" is one member of a pair of contradictories. Therefore "You are a donkey" is true.

Whereas the following is valid:

In every pair of contradictories, one member is true. "You are a donkey; You are not a donkey" is a pair of contradictories. Therefore one member of the pair "You are a donkey; You are not a donkey" is true.

(The major amounts to "Every pair of contradictories has one true member").

Where we have to deal not with a noun in an oblique case but a verb in an oblique tense or mood, the truth of an affirmative proposition in the past tense requires that the predicate should have been affirmable in the present tense, not necessarily of the same grammatical subject-term, but of the things for which that term stands, and analogously with the future tense and assertions of possibility, e.g.,

- A white thing could have been (was, will be) black $\nrightarrow$ This could have been (was, will be) the case: A white thing is black,

but

- A white thing could have been (was, will be) black $\rightarrow$ Of a thing which is white, this could have been (was, will be) the case: This is black.

(Direct translation from Burley): "Whenever a consequent follows from an antecedent, the distribution of the antecedent follows from the distribution of the consequent. For this follows: (A) man is running, therefore (an) animal is running, and so this follows: Every animal is running, therefore every man is running." 
"But there are objections to this rule."

"For this follows: Socrates is running, therefore (a) man is running; but this doesn't: Every man is running, therefore every Socrates is running, for the consequent is not intelligible."

"Again this follows: (a) man is (a) donkey, therefore (a) man is (an) animal; but this doesn't: Every man is an animal, therefore every man is a donkey."

"Again this follows: (An) animal (i.e., a certain animal) is (a) man, therefore (a) man (i.e., a certain man) is (an) animal; but this doesn't: Every man is an animal, therefore every animal is a man."

"Answers to objections: This rule is good if three conditions are assumed. The first is, that the first consequence shall hold in virtue of the terms employed and not in virtue of the structure of the proposition as a whole. The second, that those terms in virtue of which the first consequence holds, shall be distributable. The third, that the distribution shall be applied to those terms in virtue of which the first consequence is a good one. Because the first condition is not met it is not necessary that if this follows: An animal is a man, therefore a man is an animal, then this follows: Every man is an animal, therefore every animal is a man. For this consequence: An animal is a man, therefore a man is an animal, holds because of the structure of the whole sentences and not because of the terms. Because the second condition fails this does not follow: Every man is an animal, therefore every man is a donkey, although the reverse without the distribution follows, i.e. a man is a donkey, therefore a man is an animal; for the distribution is not applied to those terms in virtue of which the consequence holds. For this consequence: A man is a donkey, therefore a man is an animal, holds because of the predicates, and the reverse consequence would hold if a distribution were applied to the predicates, thus: A man is every animal, therefore a man is every donkey."

\section{References}

Abelard, P. (1956). In L. M. de Rijk (Ed.), Dialectica: First complete edition of the Parisian manuscript. Assen: Van Gorcum.

Baudry, L. (1950). La querelle des futurs contingents (Louvain 1465-1475): Textes inedits. Études de Philosophia Médiévale, 38, 134-170.

Baudry, L. (1989). The quarrel over future contingents (Louvain 1465-1475) (R. Guerlac, Trans.). Dordrecht: Kluwer Academic Publications.

Bocheński, I. (1949). Précis de logique mathématique. Bussum: F. G. Kroonder.

Bocheński, I. (1961). A history of formal logic. (I. Thomas, Trans.). Notre Dame, IN: University of Notre Dame Press.

Boehner, P. (1952). Medieval logic: An outline of its development from 1250 to c.1400. Manchester: Manchester University Press.

Boh, I. (1982). 'Consequences'. In N. Kretzmann et al. (Eds.), Cambridge history of later medieval philosophy. Cambridge: Cambridge University Press.

Buridan, J. (1966). Sophisms on meaning and truth (T. K. Scott, Trans.). New York: AppletonCentury-Crofts.

Buridani, I. (1518). In metaphysicam Aristotelis questiones, liber VI. Paris: Iodocus Badius.

Burleigh, W. (1951). In P. Boehner (Ed.), De puritate artis logicae. St. Bonaventure, NY: Franciscan Institute.

Conti, A. (2004). Walter Burley. In: E. N. Zalta (Ed.), The Stanford encyclopedia of philosophy (Fall 2004 ed.). http://plato.stanford.edu/archives/fall2004/entries/burley/.

Copeland, J. (1996). Prior's life and legacy. In J. Copeland (Ed.), Logic and reality: Essays on the legacy of Arthur Prior. Oxford: Clarendon Press. 
Dutilh Novaes, C. (2006). Formalisations après la lettre. Ph.D. thesis, Leiden University.

Flew, A. G. (Ed.). (1951). Logic and language. Oxford: Blackwell.

Geach, P. \& Kenny, A. (Eds.). (1976). Papers in logic and ethics. London: Duckworth.

Grimshaw, M. (2002). The prior Prior: Neglected early writings of Arthur N. Prior. Heythrop Journal, $43,480-495$.

Hasle, P. F., \& Øhrstrøm, P. (1997). Foundations of temporal logic-the WWW-site for Prior-studies. http://www.prior.aau.dk/

Hughes, G. (1982). John Buridan on self-reference: Chapter eight of Buridan's Sophismata (with a translation, introduction, and philosophical commentary). New York: Cambridge University Press.

Lukasiewicz, J. (1951). Aristotle's syllogistic from the standpoint of modern formal logic. Oxford: Clarendon Press.

Mates, B. (1949). Diodorean implication. Philosophical Review, 58(3), 234-242.

Mates, B. (1953). Stoic logic. Berkeley: University of California Press.

McGrath, M. (2006). Propositions. In E. N. Zalta (Ed.), The Stanford encyclopedia of philosophy (Winter 2006 ed.). http://plato.stanford.edu/archives/win2006/entries/propositions/

Moody, E. A. (1953). Truth and consequence in mediaeval logic. Amsterdam: North-Holland publishing company.

Øhrstrøm, P., \& Hasle, P. F. (1993). A. N. Prior's rediscovery of tense logic'. Erkenntnis, 39, $23-50$.

Prior, A. N. (1933). Art and the kingdom of God-a discussion. New Zealand Journal of Theology, 2(3), 230-234.

Prior, A. N. (1952a). The parva logicalia in modern dress. Dominican Studies, 5, 78-87.

Prior, A. N. (1952b). Modality de dicto and modality de re. Theoria, 18, 174-180.

Prior, A. N. (1953a). The logic of negative terms in Boethius. Franciscan Studies, 13, 1-6.

Prior, A. N. (1953b). Negative quantifiers. Australasian Journal of Philosophy, 31, 107-123.

Prior, A. N. (1953c). On propositions neither necessary nor impossible. Journal of Symbolic Logic, $18(2), 105-108$.

Prior, A. N. (1953d). On some consequentiae in Walter Burley. New Scholasticism, 26(4), 433-446.

Prior, A. N. (1953e). Review of I. M. Bocheński, Non-analytical laws and rules in Aristotle'. Journal of Symbolic Logic, 18(4), 333-334.

Prior, A. N. (1955). Diodoran modalities. Philosophical Quarterly, 5(20), 205-213.

Prior, A. N. (1957). Time and modality. Oxford: Oxford University Press.

Prior, A. N. (1958a). Diodorus and modal logic: A correction. Philosophical Quarterly, 8, 226-230.

Prior, A. N. (1958b). Epimenides the cretan. Journal of Symbolic Logic, 23(2), 261-266.

Prior, A. N. (1958c). Review of Walter Burley. In P. Boehner (Ed.), De puritate artis logicae tractatus longior. New Scholasticism, 32(1), 127-130.

Prior, A. N. (1959). Formalised syllogistic. Synthese, 11(3), 265-273.

Prior, A. N. (1962a). The formalities of omniscience. Philosophy, 37, 114-129.

Prior, A. N. (1962b). Some problems of self-reference in John Buridan. Proceedings of the British Academy, 48, 281-296. Reprinted in Geach, P., \& A. Kenny (Eds.). (1976). Papers in logic and ethics. London: Duckworth.

Prior, A. N. (1964). Some exercises in epistemic logic. In C. Rollins (Eds.), Knowledge and experience. Pittsburgh: University of Pittsburgh Press.

Prior, A. N. (1967). Past, present, and future. Oxford: Clarendon Press.

Prior, A. N. (1968). Review of Jean Buridan, Sophisms on meaning and truth. In T. K. Scott (Trans., Ed.), Philosophical Review, 77(4), 516-519.

Prior, A. N. (1969). The possibly-true and the possible. Mind, 78(312), 481-492.

Prior, A. N. (1971). Objects of thought. In P. Geach \& A. Kenny (Eds.), Oxford: Clarendon Press.

Sedley, D. (1977). Diodorus Cronus and hellenistic philosophy. Proceedings of the Cambridge Philological Society N. S., 23(203), 74-120.

Spade, P. V. (1982). The semantics of terms. In N. Kretzmann et al. (Eds.), Cambridge history of later medieval philosophy. Cambridge: Cambridge University Press.

Uckelman, S. L. (2011). Prior on an insolubilium of Jean Buridan. Synthese. doi:10.1007/ s11229-011-9940-6.

Zupko, J. A. (2003). John Buridan: Portrait of a fourteenth-century arts master. Notre Dame, IN: University of Notre Dame Press. 